\title{
LAKTOSA, LEMAK DAN PRODUKSI SUSU PADA SAPI PERAH LAKTASI YANG DIBERI TOTAL MIXED RATION BERBASIS JERAMI JAGUNG TERAMONIASI
}

(Milk Lactose, Fat and Productionin Lactating Dairy Cattle that Given Total Mixed Ration on Corn Straw Ammoniated Base)

\author{
Trijayanti, D. K ., Prasetiyono, B.W.H.E²., Kusumanti, E². \\ 1) Mahasiswa Pasca Sarjana Fakultas Peternakan Dan Pertanian Universitas Diponegoro \\ Kampus drh. Soejono Koesoemowardojo Tembalang Semarang 50275 email: \\ desti.kristina@yahoo.com \\ 2) Fakultas Peternakan Dan Pertanian Universitas Diponegoro \\ Kampus drh. Soejono Koesoemowardojo Tembalang Semarang 50275
}

Diterima: 2 Januari 2015 Disetujui: 25 Juni 2015

\begin{abstract}
ABSTRAK
Tujuan dari limbah penelitian ini mengevaluasi efek dari metode pemberian makan pada total ransum campuran (TMR) pada jagung strawbase amoniak pada susu laktosa, lemak susu, dan produksi susu pada sapi perah. Percobaan dilakukan dengan menggunakan rancangan acak kelompok (RAK) dengan 3 perlakuan dan 5 kelompok berdasarkan bulan laktasi. Perlakuan diaplikasikan pada T0 = non TMR, T1 = TMR pada dasar jerami jagung, dan $\mathrm{T} 2=\mathrm{TMR}$ pada dasar jerami jagung teramoniasi. Data dianalisis dengan analisis prosedur varians dan diikuti oleh uji kontras ortogonal. Hasil uji kontras orthogonal menunjukkan bahwa rata-rata susu laktosa dan lemak susu pada perlakuan non TMR (T0) tidak berbeda nyata $(\mathrm{p}>0,05)$ dibandingkan dengan TMR pada basis jerami jagung dengan dan tanpa amoniak. Rata-rata susu laktosa dan lemak susu pada perlakuan TMR pada basis amoniak jerami jagung (T2) secara signifikan lebih tinggi dibandingkan dengan TMR pada basis jerami jagung tanpa amoniak (T1). Rata-rata produksi susu tidak dipengaruhi oleh pengobatan ( $p>0,05)$. TMR pada basis amoniak jerami jagung (T2) menghasilkan produksi tertinggi susu terkoreksi $4 \%$ lemak adalah 2085,83 kg / laktasi. Fenomena ini menunjukkan bahwa TMR pada amonium jagung berbasis ampas efektif diterapkan oleh masyarakat untuk meningkatkan produktivitas sapi perah.
\end{abstract}

Kata kunci: Ransum Campuran Total, amoniasi, cornstraw, susu laktosa, lemak susu, susu produksi

\section{ABSTRACT}

The purpose of this research waste evaluate the effect of feeding method on total mixed ration (TMR) on ammoniated corn strawbase on milk lactose, milk fat, and milk production in dairy cows. The experiment was conducted using a randomized block design(RBD) with 3 treatments and 5 groups based on months of lactation. The treatments were applied at $T_{0}=$ non $T M R, T_{1}=T M R$ on corn straw base, and $T_{2}=$ TMR on ammoniated corn straw base. Data were analyzed by analysis of variance procedures and followed byorthogonal contrast test. Orthogonal contrasttest results showed that the average of milk lactose and milk fat on the non TMR treatment $\left(T_{0}\right)$ were not significantly different $(p>0.05)$ compared with the TMR 
on corn straw base with and without ammoniated. The average of milk lactose and milkfat onthe TMR treatment on corn straw ammoniated base $\left(T_{2}\right)$ was significantly highe rcompared with the TMR on corn straw base without ammoniated $\left(T_{1}\right)$. Mean milk production was not affected by treatment $(p>0.05)$. TMR on corn straw ammoniated base $\left(T_{2}\right)$ resulted inthe highest production of $4 \%$ fat corrected milk was $2085.83 \mathrm{~kg} /$ lactation. This phenomenon indicated that the TMR on ammoniated corn strawbase effectively applied by the community toimprove the productivity of dairy cattle.

Keywords: Total Mixed Ration, ammoniation, cornstraw, milk lactose, milk fat, milk production

\section{PENDAHULUAN}

Tanaman jagung merupakan salah satu bahan pakan yang dapat dijadikan pakan alternatif bagi ternak. Tingkat konsumsi jagung untuk pakan ternak tertinggi di Indonesia adalah Jawa Barat, Jawa Tengah, Jawa Timur, Sumatera Utara dan Sulawesi Selatan. Untuk memenuhi kebutuhan pakan yang terus meningkat ini maka penggunaan limbah tanaman jagung merupakan salah satu sumber pakan terbaik (Bunyamin et. al., 2013). Produksi jagung tahun 2012 dilaporkan oleh Badan Pusat Statistik (2012) sebesar 19,39 juta ton pipilan kering atau meningkat sebesar 9,88 persen dibanding tahun 2011.

Amoniasi merupakan salah satu perlakuan kimia yang bersifat alkalis dan 
dapat melarutkan hemiselulosa, lignin dan silika (Van Soest, 1982). Sifat basa dalam proses amoniasiakan membengkakkan serat atau memotong ikatan glikosida di dalam selulosa (proses swelling) sehingga serat menjadi mudah dihancurkan oleh mikrobamikroba didalam rumen (Umiyasih dan Wina, 2008). Perlakuan amoniasi memberikan jumlah nitrogen yang cukup dalam jerami yang dapat digunakan sebagai sumber NPN bagi ternak ruminansia (Sankat dan Bilanski, 1980).

Total Mixed Ration (TMR) disusun dari beberapa kombinasi bahan pakan ternak yang terdiri dari campuran hijauan, biji-bijian hasil samping industri pertanian dan perkebunan, maupun hasil samping perikanan serta probiotik dan premiks (Wahjuni dan Bijanti, 2006). Pakan TMR memungkinkan peternak menghemat biaya pakan dengan menggunakan varietas produk pertanian dan hijauan pakan (Lee et al., 2010). Pakan TMR dapat meningkatkan ekologi rumen dengan pakan lebih banyak (Wongnen et al., 2009; Phillips et al., 2001), membantu menjaga $\mathrm{pH}$ rumen dan rasio asetat propionat karena memberikan ransum lebih seimbang dengan tingkat serat dan konsentrat yang seragam dan meningkatkan konsumsi bahan kering( $\mathrm{Li}$ et al., 2003).

Glukosa darah merupakan prekursor utama $( \pm 80 \%)$ untuk pembentukan laktosa susu (Suhardi, 2011). Laktosa disintesis dari glukosa diserap dari aliran darah oleh kelenjar ambing. Glukosa tersebut beserta dengan galaktosa merupakan prekursor utama laktosa susu (Hansen et al., 1962). Menurut Aghsaghali dan Fathi (2012), kelenjar susu pada saat laktasi tidak dapat mensintesis glukosa dari prekursor lain karena tidak adanya glukosa-6-fosfatase sehingga tergantung pada suplai darah untuk kebutuhan glukosa. merangsang kegiatan mikroba untuk mencerna

Prekursor sintesis lemak susu seperti serat kasar merupakan bahan pembentuk asam asetat dan butirat, kadar lemak susu dapat dipengaruhi oleh tingkat kecernaan terhadap serat (Suhardi, 2011). Arora (1995) menyatakan bahwa produk akhir pencernaan serat yang utama adalah asam asetat yang sangat berpengaruh terhadap pembentukan lemak susu. Faktor yang mempengaruhi kadar lemak susu sapi antara lain jenis sapi perah, umur sapi, bulan laktasi, interval pemerahan, keadaan iklim, dan ransum yang diberikan (Basya, 1983).

Penelitian ini bertujuan untuk mengetahui pengaruh pakan total mixed ration (TMR) berbasis jerami jagung teramoniasi terhadap kadar laktosa susu, lemak susu, dan produksi susu pada sapi perah.

\section{MATERI DAN METODE}

\section{Materi}

Penelitian dilaksanakan bulan Oktober 2013 - Desember 2013 di

Peternakan Sapi Perah Tri Nugraha Farm Salatiga, Laboratorium Teknologi Pakan dan Laboratorium Ilmu Nutrisi dan Pakan Fakultas Peternakan dan Pertanian Universitas Diponegoro Semarang.

Penelitian menggunakan 15 ekor sapi perah laktasi dengan 3 perlakuan dan 5 kelompok berdasarkan bulan laktasi. Bahan yang digunakan adalah konsentrat, jerami jagung, urea, air, dan bahan-bahan kimia untuk analisis. Peralatan yang digunakan adalah peralatan pembuatan amoniasi dan peralatan analisis.

\section{Metode}

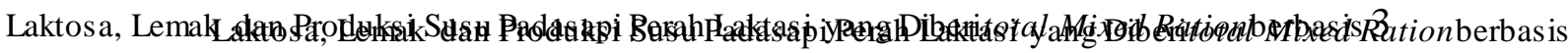
Jerami Jagung Teramoniasi 
Penelitian dilaksanakan menggunakan rancangan acak kelompok (RAK) dengan 3 perlakuan dan 5 kelompok berdasarkan bulan laktasi. Perlakuan yang diterapkan adalah sebagai berikut:

$\mathrm{T}_{0}=$ Pakan non TMR berbasis jerami jagung tanpa pengolahan

$\mathrm{T}_{1}=$ Total mixed ration berbasis jerami jagung tanpa pengolahan

$\mathrm{T}_{2}=$ Total mixed ration berbasis jerami jagung dengan pengolahan amoniasi

Penelitian dilakukan dua tahap yaitu persiapan dan pemeliharaan.Tahap persiapan selama 8 minggu meliputi a) menyiapkan kandang dan peralatan; b) mengukur berat badan dan mengelompokkan berdasar bulan laktasi; c) menempatkan sapi berdasarkan pengacakan perlakuan; d) menyiapkan ransum. Tahap pemeliharaan selama 8 minggu terdiri dari 3 minggu adaptasi dan 5 minggu pencatatan data meliputi a) mencatat pemberian ransum setiap hari; b) mencatat sisa ransum keesokan harinya; c) mencatat produksi susu pagi dan sore; d) mencatat suhu dan kelembapan lingkungan serta kontaraksi rumen: e) mengambil sampel susu, cairan rumen, feses dan darah untuk dianalisis laboratorium. Komposisi konsentrat dan kandungan nutrien pakan perlakuan dapat dilihat pada Tabel 1 .

Tabel 1. Susunan dan Kandungan Nutrien Ransum Perlakuan

\begin{tabular}{|c|c|c|c|c|}
\hline \multirow{2}{*}{ No } & \multirow{2}{*}{ Jenis bahan } & \multicolumn{3}{|c|}{ "Jumlah (\%) } \\
\hline & & T0 & T1 & $\mathrm{T} 2$ \\
\hline 1 & Jerami jagung & 40 & 40 & \\
\hline 2 & Jerami jagung amoniasi & & & 40 \\
\hline 3 & Onggok & 6 & 6 & 6 \\
\hline 4 & Brand polar & 16,05 & 16,05 & 16,05 \\
\hline 5 & Garam & 0,6 & 0,6 & 0,6 \\
\hline 6 & Bekatul & 24 & 24 & 24 \\
\hline 7 & Kulit kacang & 4,2 & 4,2 & 4,2 \\
\hline 8 & Bungkil kopra & 6 & 6 & 6 \\
\hline 9 & Premix & 0,15 & 0,15 & 0,15 \\
\hline 10 & Tetes & 0,6 & 0,6 & 0,6 \\
\hline 11 & Kalsium & 0,6 & 0,6 & 0,6 \\
\hline 12 & Soyxyl@ & 1,2 & 1,2 & 1,2 \\
\hline 13 & Go Pro@ & 0,6 & 0,6 & 0,6 \\
\hline & Jumlah & 100 & 100 & 100 \\
\hline & PK & 10,1 & 10,1 & 11,9 \\
\hline & SK & 38,5 & 38,5 & 36 \\
\hline & LK & 2,9 & 2,9 & 2,6 \\
\hline & $\mathrm{ABU}$ & 16,3 & 16,3 & 17 \\
\hline & TDN & 50,1 & 50,1 & 52,2 \\
\hline & BETN & 32,2 & 32,2 & 32,5 \\
\hline & $\mathrm{Ca}$ & 0,6 & 0,6 & 0,6 \\
\hline & $\mathrm{P}$ & 0,4 & 0,4 & 0,4 \\
\hline
\end{tabular}


Soyxyl@dan Go Pro@: merk paten suplemen protein produksi UD Berkah Intan Sentosa

Laktosa, Lemak dan Produksi Susu Padas api Perah Laktasi yang Diberitotal Mixed Rationberbasis 5 Jerami Jagung Teramoniasi 
Pembuatan amoniasi jerami jagung dilakukan dengan memotong jerami jagung 5-10 $\mathrm{cm}$, kemudian menimbang jerami jagung tersebut yang telah diketahui kadar BK. Menentukan urea yang akan digunakan untuk amoniasi jerami dengan dosis sebesar $6 \%$ dari bahan kering jerami jagung (Andayani et al., 2005). Cara menghitung kadar air yang dibutuhkan:

$$
\% \text { kadar air yang dibutuhkan }(40 \%)=x \frac{(\% \text { KA jerami } \mathrm{x} \text { gram jerami })+\mathrm{a}}{\text { gram jerami }+\mathrm{a}} \quad 100 \%
$$

Dengan, $\mathrm{a}=$ jumlah air yang ditambahkan (ml)

Susu

Pembuatan pakan TMR dilakukan dengan cara mencampur konsentrat dan jerami jagung atau jerami jagung amoniasi secara manual.

Penentuan kualitas susu dilakukan dengan menggunakan lactoscan.

Pengambilan sampel susu pada pemerahan pagi dan sore hari, kemudian dicampur hingga homogen dengan proporsi susu pemerahan pagi $5 \mathrm{ml}$ dan susu pemerahan sore $5 \mathrm{ml}$. Mempersiapkan alat lactoscan serta selang penyambung antara lactoscan dengan susu yang akan dilakukan analisis. Selang penyambung tersebut kemudian dimasukkan ke dalam botol yang telah berisi susu. Alat lactoscan dinyalakan dan proses analisis berjalan secara otomatis. Hasil analisis langsung keluar berupa data yang berisikan fat, protein dan lactose.

Semua data penelitian dianalisis berdasarkan prosedur sidik ragam dan dilanjutkan dengan uji kontras ortogonal untuk mengetahui perbedaan antar perlakuan (SAS, 1984).

\section{HASIL DAN PEMBAHASAN}

Hasil penelitian tentang kadar laktosa, lemak dan produksi susu pada sapi perah laktasi yang diberi Total Mixed Ration (TMR) berbasis jerami jagung teramoniasi dapat dilihat pada Tabel 2.

\section{Pengaruh perlakuan terhadap laktosa}

Glukosa darah merupakan prekursor utama $( \pm 80 \%)$ dan senyawa esensial untuk 
Tabel 2. Rata-rata dan Uji Kontras Ortogonal Laktosa Susu, Lemak Susu, dan Produksi Susu 4\% FCM pada Sapi Perah Laktasi

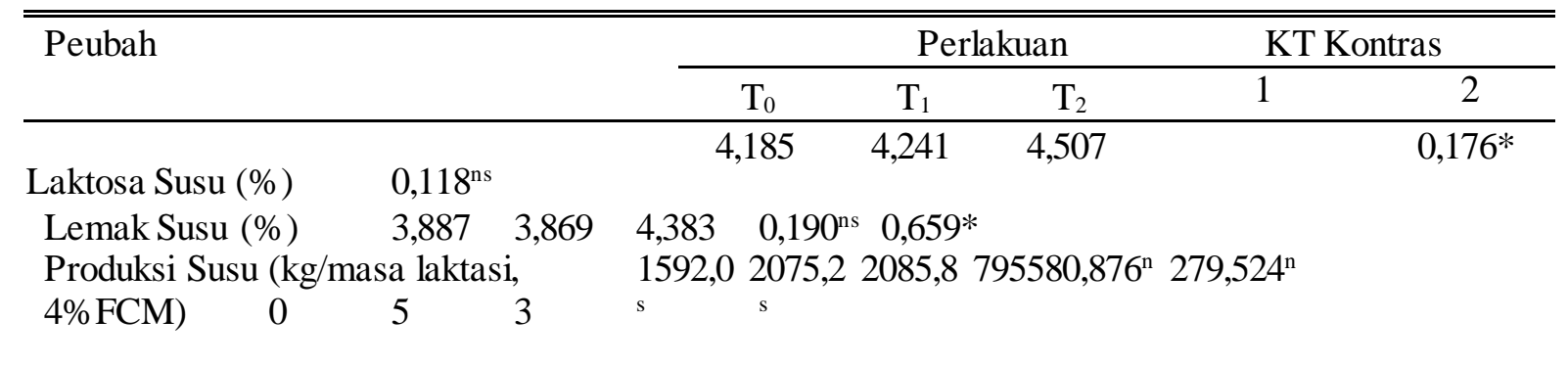

Keterangan: kontras $1=$ perbandingan $T_{0}$ vs $T_{1} T_{2}$, kontras $2=$ perbandingan $T_{1}$ vs $T_{2}$, (ns) $=$ tidak berbeda nyata $(p>0,05),(*)=$ berbeda nyata $(p<0,05),(* *)=$ berbeda sangat nyata $(\mathrm{p}<0,01), \mathrm{KT}=$ kuadrat tengah

pembentukan laktosa susu (Suhardi, 2011). Glukosa ini merupakan karbohidrat utama dalam darah sapi. Sebagian besar karbohidrat ransum diubah menjadi VFA salah satunya adalah propionat yang kemudian diubah menjadi glukosa di dalam hati. Menurut Hansen et al. (1962), laktosa disintesis dari glukosa diserap dari aliran darah oleh kelenjar ambing. Glukosa tersebut beserta dengan galaktosa merupakan prekursor utama laktosa susu. Dijelaskan lebih lanjut oleh Aghsaghali dan Fathi (2012), kelenjar susu pada saat laktasi tidak dapat mensintesis glukosa dari prekursor lain karena tidak adanya glukosa6-fosfatase sehingga tergantung pada suplai darah untuk kebutuhan glukosa.

\section{Pengaruh perlakuan terhadap lemak susu}

(BHBA) merupakan bahan-bahan utama pembentuk lemak susu yang diserap oleh kelenjar ambing. Produk akhir pencernaan serat yang utama adalah asam asetat yang sangat berpengaruh terhadap pembentukan lemak susu (Arora, 1995). Asam lemak susu berasal dari asam lemak yang diambil oleh kelenjar dari sirkulasi trigliserida dan asam lemak bebas, sintesis asetat dan BHBA yang diproduksi oleh bakteri rumen kemudian diambil oleh kelenjar, serta dari sintesis glukosa melalui asetil KoA (Jennes, 1974).

Perlakuan pakan TMR berbasis jerami jagung tanpa amoniasi dibandingkan dengan pakan TMR berbasis jerami jagung teramoniasi ( $\mathrm{T}_{1}$ vs $\left.\mathrm{T}_{2}\right)$ menghasilkan rataan kadar lemak susu pada perlakuan TMR berbasis jerami jagung teramoniasi yaitu $4,383 \%$ nyata lebih tinggi $(\mathrm{p}<0,005)$ dibandingkan dengan TMR berbasis jerami

Berdasarkan uji kontras orthogonal, jagung teramoniasi yaitu 3,869\%. Hal ini perlakuan pakan non TMR dibandingkan disebabkan perlakuan amoniasi menyebabkan dengan pakan TMR ( $\mathrm{T}_{0}$ vs $\left.\mathrm{T}_{1} \mathrm{~T}_{2}\right)$ serat mudah didegradasi oleh mikrobia rumen menunjukkan rata-rata lemak susu pada sehingga ketersediaan asupan energi berupa perlakuan non TMR $\left(\mathrm{T}_{0}\right)$ tidak berbeda glukosa meningkat.

nyata dengan perlakuan TMR berbasis Hal ini sesuai dengan pendapat (Gellrich, jerami jagung tanpa dan dengan amoniasi 2012) bahwa kecukupan energi terutama pada $\left(\mathrm{T}_{1}\right.$ dan $\mathrm{T}_{2}$ ). Hal ini diduga karena baik awal laktasi memobilisasi lemak tubuh dan pakan non TMR maupun TMR masih sehingga meningkatkan kadar lemak susu. mampu menghasilkan prekursor Glukosa diubah menjadi gliserol dan pembentuk lemak susu dengan jumlah yang digunakan sebagai prekursor dari sintesis sama untuk sintesis lemak susu pada lemak susu. Asetat dan $\beta$-hidroksibutirat kelenjar ambing. Menurut Suhardi (2011), digunakan untuk pembentukan asam lemak trigliserida darah bersama dengan glukosa yang melekat pada gliserolmembentuk darah, asetat dan asam beta hidroksi butirat lemaksusu. Setengah dari lemak susu disintesis 
di kelenjar susu, sedangkan yang lain berasal dari lipid dalam pakan.

Ransum sapi perah dengan jumlah konsentrat yang terlalu banyak dan hijauan yang terbatas akan berakibat pada penurunan produksi saliva, sehingga $\mathrm{pH}$ rumen menjadi rendah. Keadaan ini menyebabkan perbedaan komposisi asamasam lemak terbang dalam rumen sehingga produksi asam asetat menjadi berkurang. Seperti diketahui, asam asetat yang dibentuk dalam rumen merupakan bahan baku utama pembentukan lemak susu. Dengan demikian, apabila produksi asam asetat dalam rumen berkurang, akan mengakibatkan kadar lemak susu yang rendah (Basya, 1983).

\section{Pengaruh perlakuan terhadap produksi susu $4 \%$ FCM}

Berdasarkan uji kontras orthogonal menunjukkan perlakuan pakan non TMR dibandingkan dengan pakan TMR ( $\mathrm{T}_{0}$ vs $\left.\mathrm{T}_{1} \mathrm{~T}_{2}\right)$ didapatkanrata-rata produksi susu 4\% FCM pada perlakuan non TMR $\left(\mathrm{T}_{0}\right)$ tidak berbeda nyata $(\mathrm{p}>0,05)$ dibandingkan dengan perlakuan $T M R\left(T_{1}\right.$ dan $\left.T_{2}\right)$. Hal ini terjadi karena setiap produksi susu yang meningkat juga disertai penurunan kadar lemak pakan. Hal ini sesuai dengan pendapat Rock (1974) bahwa $0,39 \mathrm{~kg}$ susu mengalami penurunan pada setiap peningkatan persentase lemak $0,072 \%$, sehingga lemak susu yang meningkat tidak menyebabkan peningkatan produksi susu. Oleh sebab itu, produksi susu 4\% FCM akan memperoleh hasil yang sama pada semua perlakuan $\left(\mathrm{T}_{0}, \mathrm{~T}_{1}\right.$, dan $\left.\mathrm{T}_{2}\right)$.

Rata-rata produksi susu 4\% FCM tertinggi diperoleh pada sapi dengan pemberian pakan perlakuan TMR berbasis jerami jagung teramoniasi $\left(\mathrm{T}_{2}\right)$, yaitu 2085,83 kg/masa laktasi. Hal ini disebabkan pemberian pakan TMR dapat mempertahankan keseimbangan $\mathrm{pH}$ dalam rumen (Lee et al., 2010) dan membantu meningkatkan hasil fermentasi karena menghasilkan bakteri rumen dengan campuran bahan dan nutrien yang sama di dalam rumen sapi. Hal ini menyebabkan peningkatan produksi susu, kesehatan, dan kinerja reproduksi (Phillips et al. 2001).

Rataan produksi pada perlakuan TMR berbasis jerami jagung teramoniasi $\left(\mathrm{T}_{2}\right)$ cenderung lebih tinggi dibandingkan dengan TMR berbasis jerami jagung tanpa amoniasi $\left(\mathrm{T}_{1}\right)$. Hal ini disebabkan karena rataan kadar laktosa susu pada $\mathrm{T}_{2}$ mengalami peningkatan. Aghsaghali et al. (2012) menyatakan bahwa produksi laktosa susu yang lebih tinggi atau lebih rendah dapat mempengaruhi produksi susu. Defisiensi kompleks sintase laktosa dalam kelenjar susu yang disebabkan oleh berkurangnya $\alpha$ lactalbumin atau $\beta-1,4-$ galactosyltransferase(dua bagian dari kompleks sintase laktosa) dapat menyebabkan penurunan produksi susu disebabkan oleh penurunan biosintesis laktosa. Selain itu, menurut Musnandar (2011) bahwa produksi susu meningkat pada pemberian ransum berkadar hijauan rendah tapi kadar lemak menurun.

\section{KESIMPULAN}

Berdasarkan hasil penelitian dapat diambil kesimpulan bahwa pemberian pakan TMR dengan penambahan jerami jagung teramoniasi $\left(\mathrm{T}_{2}\right)$ mampu meningkatkan produksi susu 4\% FCM pada sapi perah dengan kandungan laktosa dan lemak susu yang baik. Pakan TMR berbasis jerami jagung teramoniasi ini efektif diterapkan oleh masyarakat untuk meningkatkan produktivitas ternak perah. 


\section{DAFTAR PUSTAKA}

Aghsaghali, A. M. and H. Fathi. 2012.

"Lactose in ruminants feeding: a review." Annuals of

Biological Research, 3 (1): 645 -650 .

Andayani, J., A. Yani, dan Akmal. 2005. "Kecernaan bahan kering, bahan organik dan NDF kulit buah jagung amoniasi secara in sacco." Laporan Penelitian. Jambi: Fakultas

Peternakan Universitas Jambi.

Arora, S. P. 1995. Pencernaan Mikrobia pada Ruminansia. Cetakan ke-2. (Diterjemahkan oleh R. Murwani). Yogyakarta: Gadjah Mada

University Press.

Badan Pusat Statistik. 2012. Laporan

Bulanan Data Sosial

Ekonomi. www.bps.go.id (Diakses pada 12 September 2014 pukul 22.33 WIB).

Basya, S. 1983. "Berbagai faktor yang mempengaruhi kadar lemak susu sapi perah." Wartazoa 1 (2): 13-15.

Bunyamin, Z., R. Efendi, dan N. N. Andayani. "Pemanfaatan limbah jagung umtuk industri

pakan ternak."

Prosiding Seminar

Nasional Inovasi

Teknologi

Pertanian. Peranan dan Aplikasi

Inovasi Teknologi

Pertanian

Mendukung Ketahanan Pangan

Nasional Banjarbaru 26-27 Maret

2013. Kalimantan Selatan, 153-166.
Productive Characterisation

of

Multiparous Cows Grouped For FatCorrected Milk Yield and Milk

Protein Concentration.”

A

Dissertation. FreisingWeihenstepha:

Tierärztlichen

Fakultät. Universität München.

Hansen, R. G., H. G. Wood, G. J. Peeters, B. Jocobson, and J. Wilken. 1962.

"Lactose synthesis: labeling of lactose precursors by glycerol1,3C14 and glucose-2-C14." J. Biol. Chem., 237: 1034 - 1039.

Jennes, R. 1974. "Biosynthesis and composition of milk." J. Investigative Dermatology 63 (1): 109-118.

Lee, S., Y. Kim, Y. Oh, and W. Kwak. 2010. "Effect of feeding methods of total mixed ration on behavior pattern of growing Hanwoo steers." Asian-Aust. J. Anim. Sci. 23 (11): 1469 - 1475.

Li, D. Y., S. S. Lee, N. J. Choi, S. Y. Lee, H. G. Sung, J. Y. Ko, S. G. Yun, and J. K. Ha. 2003. "Effects of feeding system on rumen fermentation parameters and nutrient digestibility in Holstein steers." Asian-Aust. J. Anim. Sci. 16:1482-1486.

Musnandar, E. 2011. "Efisiensi energi pada sapi perah Holstein yang diberi berbagai imbangan rumput dan konsentrat." J. Pen. Univ. Jambi Seri Sains 13 (2): 53-58.

Phillips, D. M. A., J. R. Bicudo, and L. W. Turner. 2001. Managing the Total Mixed Ration to Prevent Problems in Dairy Cows. Cooperative Extension

Gellrich, K. 2012. "Metabolic and

Laktosa, Lemak dan Produksi Susu Padasapi Perah Laktasi yang Diberitotal Mixed Rationberbasis 9

Jerami Jagung Teramoniasi 
Service. Lexington: University of Kentucky.

Rock, C. G., C. E. Polan, W. M. Etgen, and C. N. Miller. 1974. "Varying dietary fiber for lactating cows fed corn and barley silages." J. Dairy Sci. 57: 1474-1482.

Sankat, C. K. and W. K. Bilanski. 1980. "Ammoniation of corn stover stacks to improve feed value." Can. Agric. Eng. 22: $77-80$.

SAS. 1984. SAS Users Statistic. Cary, Nc: SAS Inst.

Suhardi. 2011. "Pengaruh Penggantian Rumpt Gajah dengan Jerami Padi

Amoniasi terhadap Kualitas Susu Sapi Perah." Tesis. Fakultas

Peternakan Universitas Boyolali.

Umiyasih, U. dan E. Wina. 2008.

"Pengolahan dan nilai nutrisi limbah tanaman jagung sebagai pakan ternak ruminansia." Wartazoa 18 (3): 127136.

Van Soest, P. J. 1982. Nutritional Ecology of The Ruminant. Ithaca USA:

Cornell University Press.

Wahjuni, R. S. dan R. Bijanti. 2006. 'Uji efek samping formula pakan komplit terhadap fungsi hati dan ginjal pedet sapi Friesian Holstein." Med. Ked. Hewan, 22 (3): 174-179.

Wongnen, C., C. Wachirapakorn,

C. Patipan, D. Panpong, K. Kongweha, N. Namsaen, P. Gunun, and $\mathrm{C}$.

Yuangklang. 2009. "Effects of fermented totalmixed ration and cracked cottonseed onmilk yield and milk composition in dairy cows Asian-Aust." J. Anim. Sci. 22 (12): $1625-1632$. 